\title{
For Erina
}


Robert Shaughnessy - 9781526115720

Downloaded from manchesterhive.com at $04 / 26 / 2023$ 02:39:40PM 